\title{
The yield of endometrial aspiration in women with various risk factors and bleeding abnormalities
}

\author{
Anita L. Nelson ${ }^{1,5^{*}}$, Lisa Vasquez ${ }^{3}$, Roya Tabatabai ${ }^{4}$ and Samuel S. $\mathrm{Im}^{2}$
}

\begin{abstract}
Background: Even in the face of a substantial increase in the numbers of endometrial cancer cases and in the numbers of women who have risk factors, there is no clear agreement about the indications for assessing the endometria of women with abnormal bleeding or about the tools to use in that assessment. This study sought to determine in a group of high risk women with abnormal uterine bleeding, the probability that an outpatient endometrial aspiration would identify significant pathology.

Methods: Retrospective cohort study of the histology from endometrial aspirations performed from 2001 to 2008 for abnormal uterine bleeding at Harbor-UCLA Medical Center and its satellite public health clinics. Medical records were reviewed in detail to assess risk factors, descriptions of bleeding abnormalities and histologic results.

Results: The charts of 1601 women who underwent 1636 endometrial biopsies for a wide variety of abnormal uterine bleeding patterns yielded 73 (4.6\%) cases of endometrial carcinoma, 43 cases of atypical endometrial hyperplasia (2.7\%), for an overall yield of significant pathology of $7.2 \%$. Hyperplasia without atypia was found in another 83 cases (5.2\%). Obesity, diabetes and postmenopausal age are associated with an increased risk of significant pathology. Bleeding patterns were so poorly documented that analysis of yield by this factor should be viewed with caution.

Conclusions: The probability of detecting significant uterine pathology is greatest among obese, diabetic postmenopausal women with diabetes $(26.3 \%)$. Conversely, the probability of identifying significant pathology in younger women without risk factors is less than $2 \%$. For women who perceive their individualized risk estimate to be too small to justify an endometrial biopsy, it may be possible to offer oral higher dose progestin therapy on the condition that persistent abnormal bleeding will require more intensive evaluation. These estimates of absolute risk of being diagnosed with significant pathology on endometrial biopsy may be helpful to patients as they consider giving informed consent for the procedure.
\end{abstract}

Keywords: Abnormal uterine bleeding, Endometrial aspiration, Endometrial biopsy, Endometrial carcinoma, Endometrial hyperplasia with atypia

\footnotetext{
* Correspondence: anitalnelson@earthlink.net

${ }^{1}$ Los Angeles BioMedical Research Institute at Harbor-UCLA Medical Center,

Torrance, CA, USA

${ }^{5} 1457$ 3rd Street, Manhattan Beach, CA 90266, USA

Full list of author information is available at the end of the article
} 


\section{Background}

Endometrial carcinoma is the most frequent reproductive cancer in US women; the American Cancer Society estimates that 54,870 new cases will be diagnosed in 2015 [1]. Despite better understanding of the risk factors for the most common form of endometrial carcinoma, endometrial adenocarcinoma and its precursor lesion, endometrial intraepithelial neoplasia/atypical endometrial hyperplasia, no routine screening tests are currently available. On the other hand, diagnostic testing has evolved over the last few decades. Operative curettage was first replaced by office-based sampling [2-9]. Hysteroscopic evaluation and directed biopsy [10-12], ultrasonographic assessments [13-18], saline infusion sonography [12, 19-22], and saline infusion sonographydirected endometrial biopsy [22] have followed and are used in different settings to evaluate women with abnormal bleeding for endometrial pathology.

Endometrial evaluation has generally been recommended to evaluate "abnormal uterine bleeding" in at risk women [23, 24]. ACOG has recommended endometrial sampling for women as young as age 19-39 years who do not respond to medical therapy or who have prolonged periods of unopposed estrogen stimulation. Risk factors identified included nulliparity, hypertension, body mass index $>30$, irregular menstruation and family history [25]. Most recently ACOG has characterized suspicious bleeding as irregular menses, intermenstrual bleeding and postmenopausal bleeding and said that the decision to histologically evaluate abnormal uterine bleeding in premenopausal women should be based on symptomatology and clinical presentation [26, 27]. The Canadian Society of Obstetricians and Gynecologists recommends endometrial sampling in women presenting with abnormal uterine bleeding and age over 40 or weighing more than $90 \mathrm{~kg}$ [28]. In all of these cases, the definitions of "irregular", "abnormal" and "heavy" bleeding are not standardized. Although there are multiple well established risk factors in the development of endometrial cancer including diabetes, unopposed estrogen stimulation and nulliparity [29], rarely are risk factors other than age and weight considered in the guidelines.

While much attention has been paid to the relative risks of developing endometrial cancer and to the sensitivity and specificity of these various testing modalities, one clinical question has not received as much attention: If a woman undergoes endometrial sampling, what is the probability that significant pathology will be detected to justify such invasive testing in lieu of other options, such as providing empiric progestin therapy? In the absence of consensus guidelines regarding when to perform endometrial biopsy, information regarding yield of such a procedure may assist providers and patients in making an informed decision.
Harbor-ULCA Medical Center in Torrance, California has traditionally provided care to indigent, uninsured women who have limited access to medical services. Endometrial biopsies have consistently been performed using Uterine Explora Model 1 (Cooper Surgical, Trumbull CT) with $3 \mathrm{~mm}$ OD plastic curette with cutting edges and a $10 \mathrm{cc}$ removable syringe because it has been thought that such equipment would minimize the frequency of inadequate samples. The purpose of this study was to determine the probability of finding significant endometrial pathology (hyperplasia with atypia or endometrial carcinoma) on aspiration of women with different risk factors who present with what their clinicians categorize as "abnormal bleeding". This information may guide clinicians in deciding when to recommend endometrial aspiration to individual patients and may provide patients a basis upon which to decide which to give or withhold informed consent for the procedure.

\section{Methods}

Consent to conduct this research was obtained from the Research Committee and from the John F. Wolfe Human Subjects Committee of the Los Angeles BioMedical Research Institute at Harbor-ULCA Medical Center on an exempt basis because the study posed no more than minimal risk and because no personal identifying information was collected. Each patient's chart was consulted for her age group, medical problems that might contribute to abnormal bleeding or affect her risk for having endometrial disease (including her height and weight), the dimensions of her endometrial specimen, and her histological results. An attempt was also made to extract information about the pattern of the woman's abnormal bleeding (infrequent, prolonged, and/or heavy, intermenstrual, postcoital, etc.) to provide additional criteria to aid in decision-making. Cases were excluded if the endometrial aspiration was not done solely to evaluate bleeding abnormalities, e.g. it was as part of a work-up of abnormal cervical cytology. Yields are expressed as percent of samples that were found to have significant disease (endometrial atypia or carcinoma). Atypia was included in the category of significant disease since it has been shown to be premalignant and in up to $40 \%$ of cases, there is an undetected adenocarcinoma [30]. Fishers two-tailed exact test was used to compare frequencies of outcomes; $p<0.05$ was used to define statistically significant differences.

\section{Results}

The paper charts and electronic medical records of 1601 women who presented with complaints of abnormal vaginal bleeding were reviewed. Important patient characteristics are displayed in Table 1. Perimenopausal women (age 41-50) constituted $48.3 \%$ of the study 
Table 1 Characteristics of study population by age group

\begin{tabular}{lllllll}
\hline Age group (years) & $\begin{array}{l}\text { Number endometrial } \\
\text { biopsies }\end{array}$ & $\begin{array}{l}\text { Mean BMl } \\
\left(\mathrm{kg} / \mathrm{m}^{2}\right)\end{array}$ & $\begin{array}{l}\text { Percent } \\
\text { overweight (\%) }\end{array}$ & $\begin{array}{l}\text { Percent } \\
\text { obese (\%) }\end{array}$ & $\begin{array}{l}\text { Percent } \\
\text { diabetes (\%) }\end{array}$ & $\begin{array}{l}\text { Percent with } \\
\text { leiomyoma (\%) }\end{array}$ \\
\hline$<21$ & 5 & 33.48 & 0 & 75.0 & 0 & 0 \\
$21-30$ & 88 & 39.83 & 15.7 & 82.0 & 7.9 & 9.0 \\
$31-40$ & 317 & 34.49 & 30.3 & 58.9 & 11.1 & 30.9 \\
$41-50$ & 789 & 31.57 & 27.1 & 53.8 & 12.4 & 37.2 \\
$51-55$ & 232 & 32.56 & 24.7 & 60.0 & 18.1 & 27.7 \\
$56-55$ & 173 & 34.25 & 25.4 & 60.4 & 32.0 & 17.8 \\
$>65$ & 31 & 32.07 & 16.7 & 53.3 & 26.6 & -10 \\
Total & 1,635 & 33.03 & 26.3 & 58.0 & 15.0 & 30.4
\end{tabular}

${ }^{\mathrm{a}} B M I$ body mass index

population. Patient weights ranged from 41 to $219 \mathrm{~kg}$; BMIs ranged from 17 to $83.9 \mathrm{~kg} / \mathrm{m}^{2}$ (mean $=33.02 \mathrm{~kg}$ / $\mathrm{m}^{2}$ ). Most women $(58.0 \%)$ were obese and in $31 \%$ of the cases, the woman's weight exceeded $90 \mathrm{~kg}$. Leiomyoma were reported in $29.8 \%$. In $14.7 \%$ cases, a history of diabetes was recorded; $5.3 \%$ had thyroid dysfunction; $1.9 \%$ provided a history of breast cancer and $1.1 \%$ volunteered a history of prior endometrial hyperplasia. Hemoglobin test results were reported in $78.6 \%$ of cases; those hemoglobin levels ranged from 2.1 to $16.4 \mathrm{~g} / \mathrm{dL}$ and $13.8 \%$ of women had severe anemia (hemoglobin $<8 \mathrm{~g} / \mathrm{dL}$ ). Pulse rates ranged from 40 to 135 beats per minute.

For the study population as a whole, 27 cases of atypical hyperplasia and 74 cases of uterine (non-cervical) carcinoma were diagnosed. Table 2 demonstrates the effect obesity had on the yield of finding significant pathology. While the incidence of carcinoma did not differ significantly by BMI $\left(\leq 30 \mathrm{vs}>30 \mathrm{~kg} / \mathrm{m}_{2}\right)$ overall $(4.0 \%$ vs $4.9 \%)(p=0.4)$; the incidence of atypical hyperplasia appeared more frequently in obese women $(0.7 \%$ vs $2.4 \%)(p=0.02)$. The impact of obesity was greatest in the finding of simple hyperplasia $(2.2 \%$ vs $7.3 \%)(p<0.0001)$.

However, when age is considered a slightly different picture emerges. Table 3 displays the percent of the endometrial biopsies found to have atypia or carcinoma by age and BMI groups. Again it can be seen that these abnormalities were more frequent in obese women at every age, but weight's influence was greatest in the younger women.

Table 4 displays histological findings reported by age groups for obese and non-obese diabetic vs. nondiabetic women. In every age group with sufficient numbers, women with diabetes had higher rates of significant disease (atypia or carcinoma) than those in whom diabetes had not previously been diagnosed. The highest yield $(22.4 \%)$ was seen in postmenopausal women with $\mathrm{BMI} \geq 30 \mathrm{~kg} / \mathrm{m}^{2}$ and diabetes. The prevalence of endometritis was consistently higher among younger women compared to postmenopausal women, but the frequency of atrophic findings were reversed in those two groups. Despite the routine use of large plastic aspirator with a cutting edge, one eighth $(12.58 \%)$ of the specimens were reported to be "inadequate" or "of limited value". Rates varied slightly by age, women $\leq 50$ years $(11.2 \%)$ versus $>50$ years $(17.4 \%) \quad(p=0.0017)$. These devices were designed to facilitate biopsy in the face of active bleeding. In this study, $59.7 \%$ of women were reported to have no bleeding; heavy or moderate bleeding was seen in $17.7 \%$ of patients. Volumes of specimens varied significantly; in the 1464 cases where three dimensions of the specimen were provided by the pathologist, the mean volume was $2.9 \mathrm{~mm}^{3}$, but the standard deviation was 7.4; the median volume was $1.0 \mathrm{~mm}^{3}$.

Endocervical curettage was performed in conjunction with the endometrial aspiration in 1397 cases. Cervical dysplasia was detected in 6 women and cervical carcinoma was diagnosed in 29 women, but in 8 cases those women were found to have adenocarcinoma of the cervix in conjunction with endometrial carcinoma. Therefore, only an additional 21 cervical cancers were detected only by endocervical curettage.

Table 5 displays the categories of bleeding abnormalities that prompted the aspiration (when such data could be gleaned from for the medical records) by age group and BMI group. The most common patterns were intermittent, prolonged or excessive bleeding, followed by postmenopausal bleeding.

Table 6 displays the histological outcomes of the endometrial biopsies done to evaluate women with different bleeding patterns. Postmenopausal bleeding was associated with the highest yield of significant disease (atypia or carcinoma) (16.7\%) and inadequate or limited results (17.7\%), polyps (10.7\%) and, atrophy $(22.7 \%)$. At the other extreme, women of any age who had normal menstrual intervals, but prolonged or excessive bleeding had only a $1.3 \%$ change of significant disease. A single episode of heavy or prolonged bleeding was associated with atypia or carcinoma in only $2.4 \%$ of women of all ages. 
Table 2 Yield of endometrial aspiration: impact of obesity

\begin{tabular}{|c|c|c|c|c|}
\hline \multirow[t]{2}{*}{ Pathology result } & \multicolumn{2}{|c|}{ Total population } & \multirow{2}{*}{$\begin{array}{l}\mathrm{BMI} \leq 30^{*} \\
\%\end{array}$} & \multirow{2}{*}{$\begin{array}{l}\mathrm{BMI}>30^{*} \\
\%\end{array}$} \\
\hline & Number & $\%$ & & \\
\hline Inadequate/limited & 206 & 12.6 & 14.1 & 11.5 \\
\hline Endometritis & 172 & 10.5 & 12.3 & 9.5 \\
\hline Proliferative/disordered proliferation & 444 & 27.2 & 26.9 & 27.6 \\
\hline Secretory/decidualized/menstrual & 351 & 21.5 & 24.4 & 20.6 \\
\hline Atrophy & 97 & 5.9 & 6.7 & 4.8 \\
\hline Polyp & 158 & 9.7 & 8.1 & 10.6 \\
\hline Simple hyperplasia & 89 & 5.4 & 2.2 & 7.3 \\
\hline Complex hyperplasia & 16 & 1.0 & 0.6 & 1.3 \\
\hline Hyperplasia with atypia & 27 & 1.6 & 0.7 & 2.7 \\
\hline Endometrial carcinoma & 74 & 4.5 & 4.1 & 4.9 \\
\hline Total & 1635 & 99.9 & 100.1 & 100.4 \\
\hline
\end{tabular}

* $B M l$ body mass index in $\mathrm{Kg} / \mathrm{m}^{2}$

Curiously, the bleeding patterns had little predictive influence for endocervical samples (Table 7). None of the women diagnosed with cervical dysplasia or carcinoma complained of postcoital bleeding. Only "inflammatory changes" (4.3\%) or "unremarkable endocervical mucosa" $(95.7 \%)$ were reported with postcoital bleeding.

\section{Discussion and Conclusions}

The sensitivities and specificities of diagnostic tests have been compared to a variety of standards, including hysterectomy specimens $[6,20,31-33]$, operative dilation and curettage [32, 34, 35], hysteroscopically directed biopsy/curettage $[10,11,21,33]$, and ultrasound-directed biopsy/curettage $[15,20,21,36]$. Studies have also evaluated the influence of age [37-40], weight [37-43], diabetes $[44,45]$, and cycle frequency [38, 42, 46] as risk factors for carcinoma or hyperplasia in both premenopausal and postmenopausal women. Our study sought to answer a slightly different clinical question: What is the likelihood that a woman who presents with a bleeding abnormality with a given BMI and age would have a significant disease (endometrial intraepithelial neoplasia atypical hyperplasia or carcinoma) detected by one endometrial aspiration?

The women in our study had among the highest prevalence or of endometrial cancer reported to date, which allows us to provide a more secure estimate of

Table 3 Percent of biopsies demonstrating hyperplasia with atypia or carcinoma by age and BMI groups

\begin{tabular}{lllll}
\hline BMl & \multicolumn{4}{l}{ Age (years) } \\
\cline { 2 - 5 } & $<40$ & $41-51$ & $>50$ & All \\
\hline$\leq 30$ & $2.1 \%$ & $1.9 \%$ & $12.9 \%$ & $4.8 \%$ \\
$>30$ & $5.9 \%$ & $4.0 \%$ & $14.1 \%$ & $7.3 \%$ \\
\hline
\end{tabular}

$B M I$ body mass index in $\mathrm{Kg} / \mathrm{m}^{2}$ the upper limit of the potential for disease detected by endometrial aspiration [46]. None of the women in this study was using unopposed estrogen therapy. However, the majority had BMI $>30 \mathrm{~kg} / \mathrm{m}^{2}$. Obesity is a wellrecognized as a risk factor for endometrial cancer with a 200-400 \% linear increase in risk with each point increase in BMI [47], but there is some controversy about whether obesity is more impactful among premenopausal women [35] or among postmenopausal women [40]. We found that BMI increased the risk of atypia in every age group, but carcinoma detection rates were similar in obese and non-obese women. Postcoital bleeding was not associated with cervical dysplasia or carcinoma, but given the small number of women with that complaint, this finding may not contradict the finding of Rosenthal et al. that invasive cancer is rare in women with postcoital bleeding, but more common than in the general population [48].

The premenopausal women in our study had higher risk features than earlier studies and higher rates of detection of endometrial hyperplasia (with or without atypia) and endometrial cancer, (8.8\%). Previous Investigators have reported rates of combined hyperplasia and cancer on endometrial biopsy of women presenting with abnormal bleeding ranging from 5 to $7.7 \%$ [37, 38]. The fact that our estimate of risk for all forms of pathology exceed previously reported finding supports their value as upper limits of risk.

The impact that age has on the prevalence of significant pathology had been reported in a large study of pathology reports. Again women of that age group in our study had proportionately more cases of pathology. Because we had more information about the women than earlier investigators, we were able to isolate the impacts of weight as well as known diabetes might have on the probability that significant pathology would be identified on biopsy [49]. 
Table 4 Histology by age, BMl and diabetes status (\%)

\begin{tabular}{|c|c|c|c|c|c|c|c|c|c|c|c|c|}
\hline & \multicolumn{4}{|c|}{ Age $<40$ years } & \multicolumn{4}{|c|}{ Age $41-50$ years } & \multicolumn{4}{|c|}{ Age $>50$ years } \\
\hline & \multicolumn{2}{|l|}{$\mathrm{BMI}<30$} & \multicolumn{2}{|c|}{$\mathrm{BMI} \geq 30$} & \multicolumn{2}{|l|}{$\mathrm{BMI}<30$} & \multicolumn{2}{|c|}{$\mathrm{BMI} \geq 30$} & \multicolumn{2}{|l|}{$\mathrm{BMI}<30$} & \multicolumn{2}{|l|}{$\mathrm{BMI} \geq 30$} \\
\hline & No DM & DM & No DM & DM & No DM & DM & No DM & DM & No DM & $\mathrm{DM}$ & No DM & DM \\
\hline Number of subjects & 132 & 11 & 226 & 30 & 334 & 23 & 347 & 73 & 146 & 24 & 179 & 76 \\
\hline Inadequate/limited & 12.9 & 27.3 & 10.2 & 10.0 & 12.6 & 8.7 & 8.9 & 11.1 & 15.8 & 29.2 & 16.2 & 17.1 \\
\hline Endometritis & 12.9 & 18.2 & 10.2 & 6.7 & 14.4 & 13.0 & 12.7 & 11.1 & 6.8 & 8.3 & 3.9 & 5.3 \\
\hline Proliferative/disordered & 28.0 & 36.4 & 29.6 & 13.3 & 30.5 & 26.1 & 32.3 & 24.7 & 18.5 & 16.7 & 27.4 & 9.2 \\
\hline Secretory/decidualized/menstrual & 29.5 & 18.2 & 24.3 & 10.0 & 29.0 & 39.1 & 26.2 & 24.7 & 11.0 & - & 6.1 & 7.9 \\
\hline Atrophy & 0 & 0 & 0 & 0 & 0.8 & 4.3 & 1.4 & 2.7 & 23.3 & 29.2 & 16.8 & 14.5 \\
\hline Polyp & 12.1 & 0 & 8.8 & 23.3 & 7.2 & 8.7 & 12.2 & 8.2 & 8.2 & - & 11.2 & 7.9 \\
\hline Simple hyperplasia & 2.3 & 0 & 11.1 & 16.7 & 2.7 & & 3.7 & 5.5 & 2.1 & - & 7.8 & 9.2 \\
\hline Complex hyperplasia & 0 & 0 & 0.9 & 6.7 & 0.3 & & 0 & 4.1 & 2.1 & - & 1.7 & 2.6 \\
\hline Hyperplasia with atypia & 0.8 & 0 & 2.2 & 6.7 & 0.8 & & 2.3 & 4.1 & 0.7 & - & 0.6 & 3.9 \\
\hline Endometrial carcinoma & 1.5 & 0 & 2.7 & 6.7 & 1.2 & & 0.9 & 4.1 & 11.6 & 16.7 & 8.4 & 22.4 \\
\hline
\end{tabular}

$B M I$ body mass index in $\mathrm{Kg} / \mathrm{m}^{2}, D M$ diabetes melitis

Polyps were diagnosed on pathology in $12.1 \%$ of our subjects overall. Malignancy confined to the polyp was reported in only one case, which is much lower than the $4.2 \%$ rate of malignancy or atypia found within polyps reported earlier in symptomatic postmenopausal women [50]. Because we specifically excluded women who had abnormal cervical cytology, we cannot comment on the utility of HPV testing to distinguish between cervical and endometrial cancer in women with atypical glandular changes as recommended by Castle et al. [51].

In patients with abnormal bleeding related to obesity, thyroid dysfunction, etc., a short course of hormonal therapy for abnormal of bleeding will not be curative as it would not treat the underlying condition [52]. However, prolonged therapy with progestin will prevent development of endometrial hyperplasia and control bleeding excesses until the underlying cause is addressed [53]. Progestin containing OCPs and progestin-releasing IUDs are effective in treating endometrial hyperplasia via progestin-meditated reversal of the PTEN suppressor genes $[54,55]$. The relatively low rates of significant pathology found in our study among the younger women with normal risk factors and perimenopausal women with single episodes of heavy bleeding may make those women hesitate to agree to biopsy, but to be more accepting of a therapeutic trial of progestin therapy with the understanding that persistent abnormal bleeding would change these estimates and indicate a stronger need for biopsy. The information provided by this analusis may also be helpful in calculating the cost effectiveness of screening women with different clinical presentations [40,56].

Torres et al. reported that one fourth of patients diagnosed with endometrial cancer had previous benign endometrial sample results [57]. Close follow-up is essential as are measures to prevent recurrent abnormal bleeding or development of hyperplasia, but these services often not implemented [53, 58-65]. Over $1 \%$ of

Table 5 Bleeding or ultrasound abnormalities which prompted biopsy (number specimens)

\begin{tabular}{|c|c|c|c|c|c|c|c|}
\hline \multirow[t]{2}{*}{ Bleeding or ultrasound abnormality } & \multicolumn{2}{|c|}{ Age $\leq 40$ years } & \multicolumn{2}{|c|}{ Age $41-50$ years } & \multicolumn{2}{|c|}{ Age $\geq 50$ years } & \multirow[t]{2}{*}{ Total } \\
\hline & $\mathrm{BMI}<30$ & $\mathrm{BMI} \geq 30$ & $\mathrm{BMI} \leq 30$ & $\mathrm{BMI}>30$ & $\mathrm{BMI} \leq 30$ & $\mathrm{BMI}>30$ & \\
\hline Infrequent bleeding & 20 & 85 & 50 & 23 & 6 & 15 & 199 \\
\hline Prolonged or excessive multiple episodes & 75 & 110 & 232 & 212 & 24 & 44 & 697 \\
\hline Single episode & 31 & 55 & 71 & 68 & 10 & 9 & 244 \\
\hline Intermenstrual & 18 & 21 & 40 & 37 & 13 & 7 & 136 \\
\hline Postmenopausal & 1 & 1 & 28 & 16 & 108 & 170 & 324 \\
\hline Post-coital & 4 & 6 & 5 & 6 & 3 & 1 & 24 \\
\hline Thickened endometrium (ultrasound) & 3 & 2 & 4 & 4 & 10 & 12 & 35 \\
\hline Unclassified & - & - & & 1 & 1 & - & 5 \\
\hline Total & 142 & 255 & 415 & 356 & 170 & 255 & 1593 \\
\hline
\end{tabular}


Table 6 Histologic results by bleeding or ultrasound abnormality category (\%)

\begin{tabular}{|c|c|c|c|c|c|c|c|c|}
\hline Histology & $\begin{array}{l}\text { Infrequent } \\
\text { bleeding }\end{array}$ & $\begin{array}{l}\text { Prolonged or } \\
\text { excessive multiple } \\
\text { episodes }\end{array}$ & $\begin{array}{l}\text { Prolonged or } \\
\text { excessive single } \\
\text { episode }\end{array}$ & Intermenstrual & Postmenopausal & Postcoital & $\begin{array}{l}\text { Thickened } \\
\text { endometrium }\end{array}$ & Unclassifiable \\
\hline $\begin{array}{l}\text { Infrequent/ } \\
\text { limited }\end{array}$ & 12.8 & 12.0 & 6.2 & 13.6 & 17.0 & 4.2 & 23.3 & 0 \\
\hline Endometritis & 5.3 & 13.7 & 14.2 & 12.1 & 3.3 & 16.7 & 6.7 & 0 \\
\hline $\begin{array}{l}\text { Proliferative/ } \\
\text { disordered } \\
\text { proliferation }\end{array}$ & 33.7 & 30.6 & 25.7 & 22.9 & 19.1 & 41.7 & 13.3 & 100 \\
\hline $\begin{array}{l}\text { Secretory/ } \\
\text { decidualized/ } \\
\text { menstrual }\end{array}$ & 20.3 & 27.3 & 32.8 & 22.9 & 3.3 & 8.3 & 10.0 & 0 \\
\hline Atrophy & 1.1 & 0.9 & - & 2.1 & 22.7 & 4.2 & 26.7 & 0 \\
\hline Polyploid & 11.2 & 8.3 & 11.2 & 10.7 & 10.7 & 12.5 & 6.7 & 0 \\
\hline $\begin{array}{l}\text { Simple } \\
\text { hyperplasia }\end{array}$ & 8.0 & 4.5 & 6.2 & 4.3 & 6.0 & 4.2 & 6.7 & 0 \\
\hline $\begin{array}{l}\text { Complex } \\
\text { hyperplasia }\end{array}$ & 1.6 & 0.6 & 0.8 & 0.7 & 1.2 & 0 & 6.7 & 0 \\
\hline Atypia & 2.7 & 1.0 & 1.2 & 2.9 & 2.4 & 8.3 & 0 & 0 \\
\hline $\begin{array}{l}\text { Endometrial } \\
\text { carcinoma }\end{array}$ & 3.2 & 1.0 & 0.8 & 7.9 & 14.3 & 0 & 0 & 0 \\
\hline Total & 99.9 & 100.1 & 99.8 & 100.1 & 100.0 & 100.1 & 100.1 & 100.0 \\
\hline
\end{tabular}

patients in our study presented with a history of prior endometrial hyperplasia, but none was on any suppressive therapy. This is not an isolated problem, in one series of women treated for hemoglobin $\leq 5 \mathrm{mg} / \mathrm{dL}$, due to excessive vaginal bleeding, over $25 \%$ had been previously transfused, but none of these women was on any medical therapy to control future menstrual losses [66].

Despite the large number of cases studied and the high prevalence of disease found in our study, our results are not precise. However, they can provide estimates of the upper limit of finding significant pathology with endometrial biopsy. We have analyzed the data in various combinations of risk factors to provide the most information about the absolute risk, not relative risk. We offer our data to others with interest in this area in hopes that it may be combined with data from other investigators to refine the estimates of the yield of endometrial sampling in different clinical settings [67]. However, we recognize that these data are not applicable for one of the most common clinical scenarios-bleeding in women using postmenopausal hormone therapy-since none of our subjects reported current use of those agents.

Table 7 Endocervical curettage histologic results by bleeding abnormalities (\%)

\begin{tabular}{|c|c|c|c|c|c|c|c|c|}
\hline Histologic finding & $\begin{array}{l}\text { Infrequent } \\
\text { bleeding }\end{array}$ & $\begin{array}{l}\text { Prolonged or } \\
\text { excessive multiple } \\
\text { episodes }\end{array}$ & $\begin{array}{l}\text { Prolonged or } \\
\text { excessive single } \\
\text { episode }\end{array}$ & Intermenstrual & Postmenopausal & Postcoital & $\begin{array}{l}\text { Thickened } \\
\text { endometrium }\end{array}$ & Unclassifiable \\
\hline $\begin{array}{l}\text { Infrequent/ } \\
\text { limited }\end{array}$ & 5.6 & 4.1 & 5.3 & 5.8 & 3.2 & 0 & 4.8 & 100 \\
\hline $\begin{array}{l}\text { Unremarkable } \\
\text { endocervical } \\
\text { mucosa }\end{array}$ & 88.1 & 86.6 & 84.2 & 82.5 & 85.4 & 91.3 & 71.4 & 0 \\
\hline $\begin{array}{l}\text { Inflammation/ } \\
\text { infection }\end{array}$ & 3.8 & 6.4 & 7.7 & 8.3 & 6.1 & 4.3 & 23.8 & 0 \\
\hline Polyp & 0.6 & 1.5 & 1.4 & 0.8 & 0.7 & 0 & 0 & 0 \\
\hline Dysplasia & 0.6 & 0.9 & 0.5 & 1.7 & 1.1 & 0 & 0 & 0 \\
\hline $\begin{array}{l}\text { Cervical cancer: } \\
\text { squamous }\end{array}$ & 0 & 0.2 & 0 & - & 1.8 & 0 & 0 & 0 \\
\hline $\begin{array}{l}\text { Cervical cancer: } \\
\text { endocervical }\end{array}$ & 1.3 & 0.3 & 1.0 & 0.8 & 1.8 & 0 & 0 & 0 \\
\hline Total ECC & 100.0 & 100.0 & 100.1 & 99.9 & 100.1 & 100.1 & 100.0 & 100.0 \\
\hline
\end{tabular}


As a retrospective study, we are not able to characterize the bleeding patterns with as much accuracy as would be possible in a prospective trial [68]. Accurate categorization into bleeding groups was challenging given the paucity of menstrual data recorded in some of the records. However, at a minimum, it is hoped that our detailed analysis by age group, BMI and presenting bleeding pattern may help provide more individually relevant information for the clinician and the patient to utilize when making diagnostic decisions.

\section{Condensation}

The probability of finding significant uterine pathology on endometrial aspiration varies greatly by patient risk factors and clinical presentation, but is generally less than $2 \%$ in premenopausal women with BMI $<30 \mathrm{~kg} / \mathrm{m}^{2}$ and without diabetes who complain of abnormal bleeding. The highest yield $(22.4 \%)$ was in postmenopausal women with diabetes and $\mathrm{BMI} \geq 30 \mathrm{~kg} / \mathrm{m}^{2}$.

\section{Competing interests}

Anita $L$ Nelson declares that she has received payments for research from Merck, ContraMed Agile and honoraria for participation on advisory boards or speaker bureaus for Actavis, Agile, Aspen Pharmaceutical, Bayer, ContraMed, The Female Health Company, Merck, MicroCHIPS Biotech, PharmaNest.

The rest of the authors reports no conflicts of interest for the topic covered in this article.

\section{Authors' contributions}

ALN, LV and SSI developed the study design. ALN, LV, RT collected the data. ALN performed the data analysis and provided the first draft. All authors edited each of the drafts and approved the final manuscript.

\section{Acknowledgments}

The authors thank LeRoy Nelson, MS for his extensive assistance in analyzing the data, Jennifer Haddad for her tireless data input efforts, and the Medical Records Department of Harbor-UCLA for retrieving thousands of patient charts for our review.

No financial support was provided for this study.

\section{Author details}

${ }^{1}$ Los Angeles BioMedical Research Institute at Harbor-UCLA Medical Center, Torrance, CA, USA. ${ }^{2}$ Department of Obstetrics and Gynecology, Harbor-UCLA Medical Center, Torrance, CA, USA. ${ }^{3}$ Department Obstetrics and Gynecology, Healthcare Partners, Montebello, CA, USA. ${ }^{4}$ Department of Hematology and Oncology, Olive View-UCLA Medical Center, Sylmar, CA, USA. ${ }^{5} 1457$ 3rd Street, Manhattan Beach, CA 90266, USA.

Received: 15 January 2016 Accepted: 23 April 2016

Published online: 08 June 2016

\section{References}

1. American Cancer Society. Cancer facts \& figures 2015. Atlanta: American Cancer Society; 2015. http:/www.cancer.org/acs/groups/content/@editorial/ documents/document/acspc-044552.pdf. Last Accessed 28 Apr 2016.

2. Word B, Gravlee LC, Wideman GL. The fallacy of simple uterine curettage. Obstet Gynecol. 1958;12:642-8.

3. Dijkhuizen FP, Mol BW, Brölmann HA, Heintz AP. The accuracy of endometrial sampling in the diagnosis of patients with endometrial carcinoma and hyperplasia: a meta-analysis. Cancer. 2000;89:1765-72.

4. Kaunitz AM, Masciello A, Ostrowski M, Rovira EZ. Comparison of endometrial biopsy with the endometrial Pipelle and Vabra aspirator. J Reprod Med. 1988:33:427-31.
5. Cornier E. The Pipelle: a disposable device for endometrial biopsy. Am J Obstet Gynecol. 1984;148:109-10.

6. Ferry J, Farnsworth A, Webster M, Wren B. The efficacy of the pipelle endometrial biopsy in detecting endometrial carcinoma. Aust N Z J Obstet Gynaecol. 1993;33:76-8.

7. Alfhaily F, Ewies AA. The first-line investigation of postmenopausal bleeding: transvaginal ultrasound scanning and endometrial biopsy may be enough. Int J Gynecol Cancer. 2009;19:892-5.

8. Medverd JR, Dubinsky TJ. Cost analysis model: US versus endometrial biopsy in evaluation of peri- and postmenopausal abnormal vaginal bleeding. Radiology. 2002;222:619-27.

9. Kazandi M, Okmen F, Ergenoglu AM, et al. Comparison of the success of histopathological diagnosis with dilatation-curettage and Pipelle endometrial sampling. J Obstet Gynaecol. 2012;32(8):790-4.

10. Tinelli $R$, Tinelli FG, Cicinelli $E$, et al. The role of hysteroscopy with eyedirected biopsy in postmenopausal women with uterine bleeding and endometrial atrophy. Menopause. 2008:15:737-42.

11. Lasmar RB, Dias R, Barrozo PR, et al. Prevalence of hysteroscopic findings and histologic diagnoses in patients with abnormal uterine bleeding. Fertil Steril. 2008;89:1803-7.

12. Soguktas $\mathrm{S}$, Cogendez E, Kayatas $\mathrm{SE}$, et al. Comparison of saline infusion sonohysterography and hysteroscopy in diagnosis of premenopausal women with abnormal uterine bleeding. Eur J Obstet Gynecol Reprod Biol. 2012;161(1):66-70

13. Gull B, Carlsson S, Karlsson B, et al. Transvaginal ultrasonography of the endometrium in women with postmenopausal bleeding: is it always necessary to perform an endometrial biopsy? Am J Obstet Gynecol. 2000; 182:509-15.

14. Gull B, Karlsson B, Milsom I, Granberg S. Can ultrasound replace dilation and curettage? A longitudinal evaluation of postmenopausal bleeding and transvaginal sonographic measurement of the endometrium as predictors of endometrial cancer. Am J Obstet Gynecol. 2003;188:401-8.

15. Epstein E, Ramirez A, Skoog L, Valentin L. Dilatation and curettage fails to detect most focal lesions in the uterine cavity in women with postmenopausal bleeding. Acta Obstet Gynecol Scand. 2001;80:1131-6.

16. Epstein $E$, Valentin L. Rebleeding and endometrial growth in women with postmenopausal bleeding and endometrial thickness $<5 \mathrm{~mm}$ managed by dilatation and curettage or ultrasound follow-up: a randomized controlled study. Ultrasound Obstet Gynecol. 2001;18:499-504.

17. Gale A, Dey P. Postmenopausal bleeding. Menopause Int. 2009;15:160-4.

18. Timmermans A, Opmeer BC, Khan KS, Bachmann LM, et al. Endometrial thickness measurement for detecting endometrial cancer in women with postmenopausal bleeding: a systematic review and meta-analysis. Obstet Gynecol. 2010;116(1):160-7.

19. Goldstein SR. Saline infusion sonohysterography. Clin Obstet Gynecol. 1996; 39:248-58.

20. Spicer JM, Siebert I, Kruger TF. Postmenopausal bleeding: a diagnostic approach for both private and public sectors. Gynecol Obstet Invest. 2006; 61:174-8.

21. O'Connell $L P$, Fries $M H$, Zeringue $E$, Brehm W. Triage of abnormal postmenopausal bleeding: a comparison of endometrial biopsy and transvaginal sonohysterography versus fractional curettage with hysteroscopy. Am J Obstet Gynecol. 1998:178:956-61.

22. Moschos E, Ashfaq R, Mclntire DD, et al. Saline-infusion sonography endometrial sampling compared with endometrial biopsy in diagnosing endometrial pathology. Obstet Gynecol. 2009;113:881-7.

23. Novack's Gynecology, 13th ed. Philadelphia: Lippincott Williams \& Wilkins; 2002.

24. Berek \& Hacker's Gynecologic Oncology, 5th ed. Philadelphia: Lippincott Williams \& Wilkins; 2005. p. 398

25. Committee on Practice Bulletins-Gynecology. Practice Bulletin No. 136: Management of abnormal uterine bleeding associated with ovulatory dysfunction. Obstet Gynecol. 2013;122(1):176-85.

26. American College of Obstetricians and Gynecologists. ACOG Practice Bulletin No. 149: Endometrial cancer. Obstet Gynecol. 2015;125(4):1006-26.

27. American College of Obstetricians and Gynecologist. ACOG Committee Opinion No. 557: Management of actue abnormal uterine bleeding in nonpregnant reproductive-aged women. Obstet Gynecol. 2013;121(4):891-6.

28. Vilos $\mathrm{G}$, Lefebvre $\mathrm{G}$, Graves $\mathrm{G}$. Guidelines for the management of abnormal uterine bleeding. J Obstet Gynaecol Can. 2001;23:704-9.

29. Van den Bosch T, Coosemans A, Morina M, et al. Screening for uterine tumours. Best Pract Res Clin Obstet Gynaecol. 2012;26(2):257-66. 
30. Sorosky Jl. Endometrial cancer. Obstet Gynecol. 2012;120(2 Pt 1):383-97.

31. Zorlu CG, Cobanoglu O, Ișik AZ, et al. Accuracy of Pipelle endometrial sampling in endometrial carcinoma. Gynecol Obstet Invest. 1994;38:272-5.

32. Suh-Burgmann E, Hung YY, Armstrong MA. Complex atypical endometrial hyperplasia: the risk of unrecognized adenocarcinoma and value of preoperative dilation and curettage. Obstet Gynecol. 2009;114:523-9.

33. Elsandabesee D, Greenwood P. The performance of Pipelle endometrial sampling in a dedicated postmenopausal bleeding clinic. J Obstet Gynaecol. 2005;25:32-4.

34. Stock RJ, Kanbour A. Prehysterectomy curettage. Obstet Gynecol. 1975;45: $537-41$

35. Huang GS, Gebb JS, Einstein MH, et al. Accuracy of preoperative endometrial sampling for the detection of high-grade endometrial tumors. Am J Obstet Gynecol. 2007;196:243. e1-5.

36. Goldstein SR. Modern evaluation of the endometrium. Obstet Gynecol. 2010;116:168-76.

37. Farquhar CM, Lethaby $A$, Sowter $M$, et al. An evaluation of risk factors for endometrial hyperplasia in premenopausal women with abnormal menstrual bleeding. Am J Obstet Gynecol. 1999:181:525-9.

38. Ash SJ, Farrell SA, Flowerdew G. Endometrial biopsy in DUB. J Reprod Med. 1996;41:892-6

39. Viola AS, Gouveia D, Andrade L, et al. Prevalence of endometrial cancer and hyperplasia in non-symptomatic overweight and obese women. Aust N Z J Obstet Gynaecol. 2008;48:207-13.

40. Havrilesky LJ, Maxwell GL, Myers ER. Cost-effectiveness analysis of annual screening strategies for endometrial cancer. Am J Obstet Gynecol. 2009;200: 640. e1-8.

41. Horn LC, Schnurrbusch U, Bilek K, et al. Risk of progression in complex and atypical endometrial hyperplasia: clinicopathologic analysis in cases with and without progestogen treatment. Int J Gynecol Cancer. 2004;14:348-53.

42. Schmeler KM, Soliman PT, Sun CC, et al. Endometrial cancer in young, normal-weight women. Gynecol Oncol. 2005;99:388-92.

43. Epplein $M$, Reed SD, Voigt LF, et al. Risk of complex and atypical endometrial hyperplasia in relation to anthropometric measures and reproductive history. Am J Epidemiol. 2008;168:563-70. discussion 571-6.

44. O'Mara BA, Byers T, Schoenfeld E. Diabetes mellitus and cancer risk: a multisite case-control study. J Chronic Dis. 1985;38:435-41.

45. Adami HO, McLaughlin J, Ekbom A, et al. Cancer risk in patients with diabetes mellitus. Cancer Causes Control. 1991;2:307-14.

46. Tingthanatikul Y, Choktanasiri W, Rochanawutanon M, Weerakeit S. Prevalence and clinical predictors of endometrial hyperplasiain anovulatory women presenting with amenorrhea. Gynecol Endocrinol. 2006;22:101-5.

47. Bianchini F, Kaaks R, Vainio H. Overweitht, obesity, and cancer risk. Lancet Oncol. 2002;3(9):565-74.

48. Rosenthal AN, Panoskaltsis T, Smith T, Soutter WP. The frequency of significant pathology in women attending a general gynaecological service for postcoital bleeding. BJOG. 2001;108(1):103-6.

49. Iram S, Musonda P, Ewies AA. Premenopausal bleeding: When should the endometrium be investigated?-A retrospective non-comparative study of 3006 women. Eur J Obstet Gynecol Reprod Biol. 2010;148:86-9.

50. Lee SC, Kaunitz AM, Sanchez-Ramos L, Rhatigan RM. The oncogenic potential of endometrial polyps: a systematic review and meta-analysis. Obstet Gynecol. 2010;116(5):1197-205.

51. Castle PE, Fetterman B, Poitras N, Lorey T, Shaber R, Kinney W. Relationship of atypical glandular cell cytology, age, and human papillomavirus detection to cervical and endometrial cancer risks. Obstet Gynecol. 2010; 115(2 Pt 1):243-8.

52. Mackintosh ML, Crosbie EJ. Obesity-driven endometrial cancer: is weight loss the answer? BJOG. 2013;120(7):791-4.

53. Fader AN, Arriba LN, Frasure HE, von Gruenigen VE. Endometrial cancer and obesity: epidemiology, biomarkers, prevention and survivorship. Gynecol Oncol. 2009;114:121-7.

54. Kim MK, Seong SJ, Kim YS, et al. Combined medroxyprogesterone acetate/ levonorgestrel-intrauterine system treatment in young women with earlystage endometrial cancer. Am J Obstet Gynecol. 2013;209(4):358. e1-4.

55. Hubbs JL, Saig RM, Abaid LN, Bae-Jump VL, Gehrig PA. Systemic and local hormone therapy for endometrial hyperplasia and early adenocarcinoma. Obstet Gynecol. 2013;121(6):1172-80.

56. Kwon JS, Lu KH. Cost-effectiveness analysis of endometrial cancer prevention strategies for obese women. Obstet Gynecol. 2008;112(1):56-63.
57. Torres ML, Weaver AL, Kumar S, et al. Risk factors for developing endometrial cancer after benign endometrial sampling. Obstet Gynecol. 2012;120(5):998-1004.

58. Lin MC, Burkholder KA, Viswanathan AN, et al. Involution of latent endometrial precancers by hormonal and nonhormonal mechanisms. Cancer. 2009;15:115. 2111-8.

59. Ørbo A, Rise CE, Mutter GL. Regression of latent endometrial precancers by progestin infiltrated intrauterine device. Cancer Res. 2006;66:5613-7.

60. Ørbo A, Arnes M, Hancke C, et al. Treatment results of endometrial hyperplasia after prospective D-score classification: a follow-up study comparing effect of LNG-IUD and oral progestins versus observation only. Gynecol Oncol. 2008;111:68-73

61. Trimble CL, Method M, Leitao M, et al. Society of Gynecologic Oncology Clinical Practice Committee. Management of endometrial precancers. Obstet Gynecol. 2012:120(5):1160-75.

62. Reed SD, Voigt LF, Newton KM, et al. Progestin therapy of complex endometrial hyperplasia with and without atypia. Obstet Gynecol. 2009; 113(3):655-62.

63. Ewies AA, Alfhaily F. Use of levonorgestrel-releasing intrauterine system in the prevention and treatment of endometrial hyperplasia. Obstet Gynecol Surv. 2012;67(11):726-33.

64. Gunderson CC, Fader AN, Carson KA, Bristow RE. Oncologic and reproductive outcomes with progestin therapy in women with endometrial hyperplasia and grade 1 adenocarcinoma: a systematic review. Gynecol Oncol. 2012;125(2):477-82.

65. Kudesia R, Singer T, Caputo TA, et al. Reproductive and oncologic outcomes after progestin therapy for endometrial complex atypical hyperplasia or carcinoma. Am J Obstet Gynecol. 2014;210(3):255. e1-4.

66. Nelson AL, Ritchie JJ. Severe anemia from heavy menstrual bleeding requires heightened attention. Am J Obstet Gynecol. 2015;213(1):97. e1-6.

67. Damle RP, Dravid NV, Suryawanshi KH, et al. Clinicopathological spectrum of endometrial changes in peri-menopausal and post-menopausal abnormal uterine bleeding: A 2 years study. J Clin Diagn Res. 2013;7(12):2774-6.

68. Smithling KR, Savella G, Raker CA, Matteson KA. Preoperative uterine bleeding pattern and risk of endometrial ablation failure. Am J Obstet Gynecol. 2014;211(5):556. e1-6.

\section{Submit your next manuscript to BioMed Central and we will help you at every step:}

- We accept pre-submission inquiries

- Our selector tool helps you to find the most relevant journal

- We provide round the clock customer support

- Convenient online submission

- Thorough peer review

- Inclusion in PubMed and all major indexing services

- Maximum visibility for your research

Submit your manuscript at www.biomedcentral.com/submit
Biomed Central 